\title{
Understanding Relationship Marketing and Loyalty Program Effectiveness in Global Markets
}

\author{
Joshua T. Beck, Kelly Chapman, and Robert W. Palmatier
}

\begin{abstract}
Relationship marketing (RM) and loyalty programs (LPs) are key differentiation strategies for firms facing increasing global competition. Accordingly, global interest in RM and LPs has surged, though researchers examining these marketing activities typically apply U.S.-centric frameworks to international research contexts. To understand how RM and LPs may be influenced by factors that distinguish global markets, this review offers a comprehensive framework of both RM and LP mechanisms and considers how cultural and developmental contingency factors may alter the effects of these mechanisms on seller performance. The results from this review produce eight propositions about where specific RM and LP strategies should be most effective. By considering these mechanisms jointly, the authors also simultaneously delineate RM and LP theories and broaden the scope of global research in both domains.
\end{abstract}

Keywords: relationship marketing, loyalty programs, culture, economic development, international marketing

$\mathrm{T}$ he groundswell of international interest in relationship marketing (RM) and loyalty programs (LPs), both in practice and as a substantive area of academic research, stems from the strategic competitive advantages associated with robust buyer-seller relationships (Palmatier et al. 2013; Samaha, Beck, and Palmatier 2014; Tuli, Bharadwaj, and Kohli 2010); the increasing importance of foreign trade, such that foreign receipts are nearly half of total revenues for U.S. firms with foreign trade (Silverblatt and Guarino 2011); and the proliferation of U.S.-based business theories abroad (The Economist 2004; Nelson 2011). For U.S. sellers, both RM and LPs serve as key differentiation strategies, and perhaps as a result, most research into these strategies adopts U.S.-centric frameworks, with negligible consideration of how systemic differences between

Joshua T. Beck is Assistant Professor, Lindner College of Business, University of Cincinnati (e-mail: joshua.beck@uc.edu). Kelly Chapman is a doctoral student, Foster School of Business, University of Washington (e-mail: kjchapma@uw.edu). Robert W. Palmatier is Professor of Marketing and John C. Narver Chair in Business Administration, Foster School of Business, University of Washington (e-mail: palmatrw@uw.edu). Bulent Menguc served as associate editor for this article. countries could influence the effectiveness of RM and LPs (Samaha, Beck, and Palmatier 2014). Yet the expanding interest in RM and LPs is global in nature; according to ISI Web of Science, the number of research articles per year examining RM or customer loyalty as a topic tripled from 2003 to 2013, and scholars outside the United States accounted for approximately $80 \%$ of this increase.

Thus, to understand how the effectiveness of RM and LPs varies across global markets, we review the mechanisms that underpin RM and LP effectiveness and consider how their effects might be amplified by factors that differ across global markets. Ultimately, the aim of our review is to establish a comprehensive map of RM and LP mechanisms, collate the contingency factors that may influence the effectiveness of RM and LPs worldwide, and offer specific predictions about how certain contingency factors moderate the benefits of RM and LP

Journal of International Marketing (02015, American Marketing Association

Vol. 23, No. 3, 2015, pp. 1-21

ISSN 1069-0031X (print) 1547-7215 (electronic) 
Figure 1. Conceptual Framework: Moderating Effects of International Contingency Factors on LP and RM Effectiveness

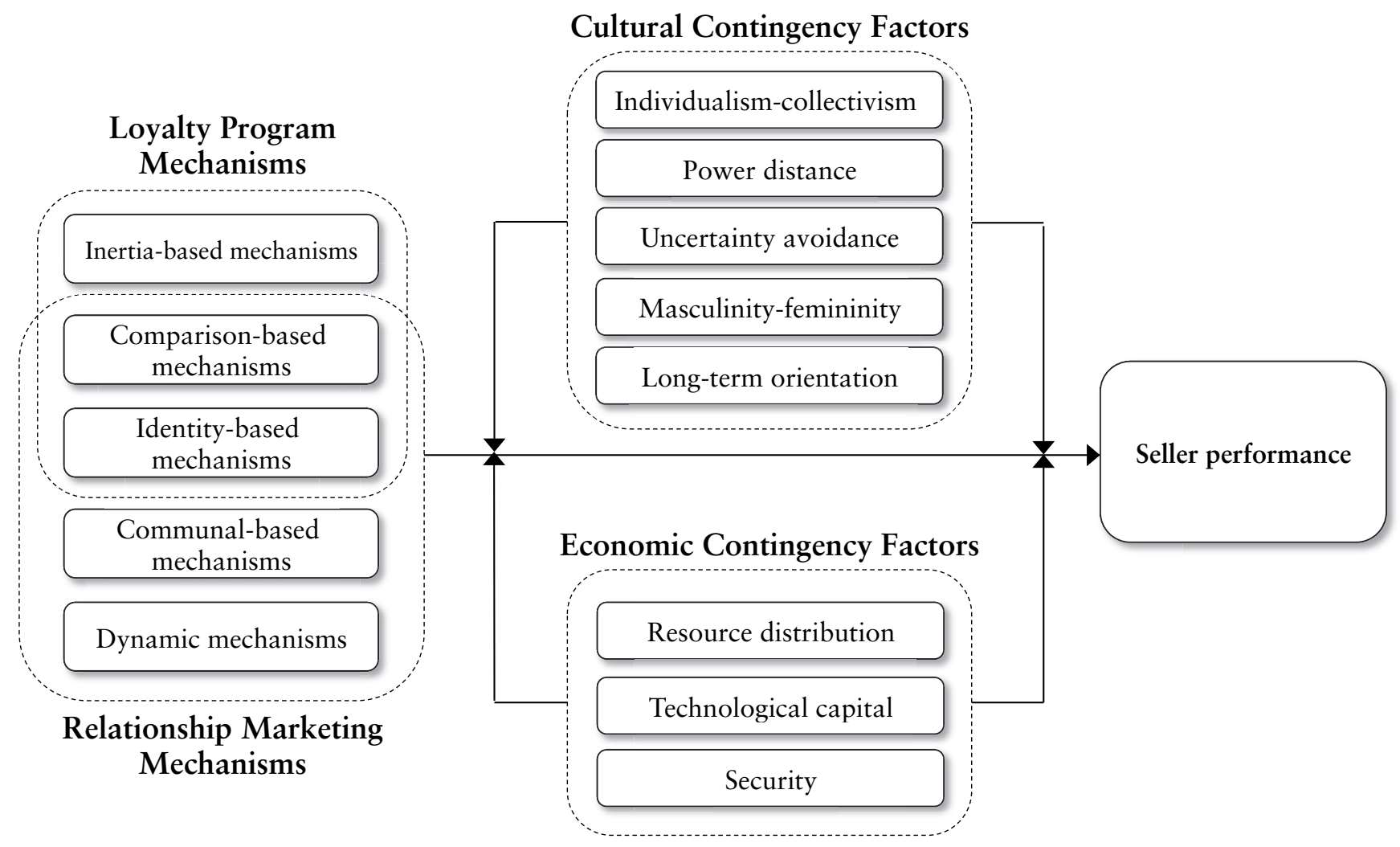

mechanisms for seller performance. Figure 1 illustrates our conceptual model.

This research advances international RM and LP research in several key ways by addressing the simple but important question, "How should efforts to build customer relationships and loyalty be adapted across countries?" First, we extend extant international customer loyalty frameworks (Kumar et al. 2013) by delineating and offering propositions specific to the unique and common mechanisms underlying the effects of RM and LPs. For example, we propose that inertiabased mechanisms (e.g., habit), which primarily underlie LPs but not RM, are more effective in countries whose cultures avoid uncertainty and in those with large accumulations of technological capital. This proposition may be specifically useful to companies expanding retail operations in foreign markets (Swoboda and Elsner 2013) and generally useful to practitioners who are increasingly interested in building profitable customer habits in developed economies (Marketing Science Institute 2014; Shah, Kumar, and Kim 2014).

Second, we consider the moderating effects of economic development in addition to culture. Culture, which develops and endures over centuries (Hofstede, Hofstede, and Minkov 2010), has been a primary focus of international marketing research (Sojka and Tansuhaj 1995), whereas economic development, which fluctuates more in the short run (Piketty 2014; Schumpeter 1934), is often overlooked, despite its importance. This approach provides a framework that bridges previous theory and informs substantive managerial decisions, such as how to adapt RM investments across export partners to leverage local cultural and economic conditions (Zeriti et al. 2014). Overall, we offer 8 propositions (comprising 14 predictions overall) as to where RM and LPs will be most effective.

Third, in this review we outline an agenda for further research based on our proposed framework. For exam- 
ple, further research may consider how the cultural and economic factors presented in our framework influence "dark side" outcomes of RM and LPs, such as how the special treatment of some customers can cause envy and disloyalty among unrewarded customers (Steinhoff and Palmatier 2014). In addition, we suggest that future researchers should consider exchange context, such as whether the exchange involves a high level of service (Voss, Roth, and Chase 2008). We may expect, for example, that communal-based RM strategies are more effective in collectivist cultures and when service levels are higher-and service level may interact with culture to ultimately determine the performance of RM strategies. Overall, we generate multiple paths for further research and offer fresh insights to international RM and LP management.

\section{MECHANISMS UNDERLYING RM AND LP EFFECTIVENSS}

Relationship marketing is broadly defined as "all marketing activities directed towards establishing, developing, and maintaining successful relational exchanges" (Morgan and Hunt 1994, p. 22). Strategies that build customer relationships enhance sales and profit over time, especially when sellers adopt these strategies before competitors and when competitive intensity is high (Kumar et al. 2011). Loyalty programs, which often have relationship building as a goal, typically include "a variety of marketing initiatives, including reward cards, gifts, tiered service levels, dedicated support contacts, and other methods that positively influence consumers' attitudes and behaviors toward the brand or firm" (Henderson, Beck, and Palmatier 2011, p. 258). Because in the modern marketplace sellers increasingly face global competition and commoditization of products and services, RM and LPs represent key differentiation strategies (Palmatier et al. 2006; Stahl et al. 2012).

With this foundation, we review mechanisms unique to RM and LPs, as well as those that are common to both (e.g., when LPs constitute RM strategies). To build our conceptual framework, we have reviewed extant frameworks (Henderson, Beck, and Palmatier 2011; Palmatier et al. 2006) and recent extensions, including dynamic mechanisms (Palmatier et al. 2013), to develop a comprehensive map of current RM and LP theory. To specify how the effects of RM and LP mechanisms on seller performance vary across countries, we first thematically categorize and review mechanisms that underlie the effects of RM and LP on performance (i.e., main effects), as Table 1 outlines, and then consider how these mechanisms might be moderated by global market contingency factors, as Table 2 outlines subsequently.

\section{Inertia-Based Mechanisms}

Inertia-based mechanisms enhance seller performance by increasing the advantages of prior behaviors (e.g., repurchasing from a known seller) relative to new behaviors (e.g., purchasing from a competing seller), usually through the cognitive ease associated with duplicating previous actions (Wood and Neal 2009). These mechanisms often establish the effectiveness of LPs (LiuThompkins and Tam 2013). For example, a loyalty rewards card may increase retention by cuing shopping behavior at a specific store (Henderson, Beck, and Palmatier 2011). The effectiveness of inertia-based mechanisms is evident in customer purchase data: as much as $85 \%$ of customer needs are satisfied through repeat brand purchases (Schneider and Hall 2011), even though customers rarely exhibit actual emotional attachment to the brands they repeatedly buy (The Economist 2014). In this sense, inertia-based mechanisms may operate outside traditional RM mechanisms, such as trust and commitment. We consider habit, cognitive lock-in, and economic switching costs.

Habits are the "associations between situational cues and repeatedly performed behavior options" (Tobias 2009 , p. 409). Customers with strong habits rarely stray from their previous behaviors, and LPs often activate habits by reinforcing situational cues, such as accrued reward points, that trigger associated purchase behaviors (Henderson, Beck, and Palmatier 2011). For example, a club card that dangles from a customer's key chain might serve simultaneously as a reminder of the customer's intention to buy milk and a cue to buy milk from the seller that offers the club card. Although habit underlies the effectiveness of many LPs, the programs also can undermine or break habits if they introduce new situational cues, such as when LPs promote complementary products and thus interrupt habitual purchases or reduce retention (Liu-Thompkins and Tam 2013). However, we focus on the positive effects of habits that LPs reinforce. On an international level, habits likely are pervasive but can vary at the category level, depending on the cultural tradition. For example, habitual tea and juice drinking in the Czech Republic has limited the success of cola brands in that market (De Mooij 2004).

Similar to cue-based habits, cognitive lock-in, which refers to cognitive barriers created by brand-specific 
Table 1. Review of Research into RM and LP Mechanisms

\begin{tabular}{|c|c|c|c|}
\hline Mechanism & Definition & Key International Findings & Business Examples \\
\hline \multicolumn{4}{|c|}{ Inertia-Based Mechanisms } \\
\hline Habit & $\begin{array}{l}\text { "Slowly developed associa- } \\
\text { tions between situational } \\
\text { cues and repeatedly per- } \\
\text { formed behavior options" } \\
\text { (Tobias } 2009, \text { p. } 409)\end{array}$ & $\begin{array}{l}\text { Habits are pervasive but can } \\
\text { vary at the category level, } \\
\text { depending on country-specific } \\
\text { traditions (De Mooij 2004). }\end{array}$ & $\begin{array}{l}\text { Tea and juice brands in the Czech } \\
\text { Republic enjoy natural barriers to } \\
\text { competition from cola brands due } \\
\text { to pervasive beverage consump- } \\
\text { tion habits (De Mooij 2004). }\end{array}$ \\
\hline Cognitive lock-in & $\begin{array}{l}\text { Cognitive barriers created } \\
\text { by brand-specific knowl- } \\
\text { edge investments (Mur- } \\
\text { ray and Häubl 2007) }\end{array}$ & $\begin{array}{l}\text { Cognitive lock-in is a competi- } \\
\text { tive advantage for well-under- } \\
\text { stood domestic brands; foreign } \\
\text { brands may compete better in } \\
\text { less familiar categories (Batra } \\
\text { et al. 2000). }\end{array}$ & $\begin{array}{l}\text { Early education investments in the } \\
\text { Chinese market protected Volk- } \\
\text { swagen from competitors; cus- } \\
\text { tomers were hesitant to learn a } \\
\text { competing foreign supplier's new } \\
\text { policies and procedures (Frynas, } \\
\text { Mellahi, and Pigman 2006). }\end{array}$ \\
\hline $\begin{array}{l}\text { Economic switching } \\
\text { costs }\end{array}$ & $\begin{array}{l}\text { Losses arising from transi- } \\
\text { tions between products } \\
\text { or competitors (Jones, } \\
\text { Mothersbaugh, and } \\
\text { Beatty 2000) }\end{array}$ & $\begin{array}{l}\text { Collectivist cultures may be } \\
\text { more likely to risk financial } \\
\text { losses, because they are sup- } \\
\text { ported by large social net- } \\
\text { works (Mandel 2003). }\end{array}$ & $\begin{array}{l}\text { Chinese customers are more likely } \\
\text { to switch to high-risk investment } \\
\text { products because of their higher } \\
\text { tolerance of downside risks } \\
\text { (Weber and Hsee 1998). }\end{array}$ \\
\hline
\end{tabular}

\section{Comparison-Based Mechanisms}

Prestige

Respect and admiration based on achievement, success, or knowledge (Cheng et al. 2013)
Envy

Out-group dissociation

Emotional discontent based on inferior position or inferior receipt of benefits provided relative to others (Feather and Sherman 2002)

\section{Identity-Based Mechanisms}

In-group association

Pursuit of association with desired reference groups (White and Dahl 2006)

Avoidance of association with undesired reference groups (White and Dahl 2006)
Relationships with foreign brands enhance prestige in emerging economies as foreign brands are symbolic of achievement (Zhou and Hui 2003).

The positive effects of envy on purchase intentions are reversed in egalitarian cultures that value modesty (Watson et al. 1999).

The effect of in-group brand association on performance is stronger in more developed countries, where foreign brands are less prestigious (De Mooij 2004).

Conflict between home and foreign countries can strengthen the negative effect of foreign country dissociation on performance. (Carvalho 2004).
Bufori's prestige-based promotion strategy targeted toward male consumers failed in Malaysia, whose culture emphasizes more equality between genders (De Mooij 2004).

Many customers own multiple cars in masculine cultures such as Germany and the United Kingdom, whereas car ownership rates are lower in countries such as the Netherlands and Scandinavia (De Mooij 2000).

Japanese advertisements insert domestic symbols (e.g., Mount Fuji) in foreign brand communications to increase in-group associations (Keillor and Hult 1998).

Chanel's Égoïste fragrance commecial was confusing and "too French" for U.S. consumers, even though Chanel was a familiar brand (Curry 2009). 
Table 1. Continued

\begin{tabular}{|c|c|c|c|}
\hline Mechanism & Definition & Key International Findings & Business Examples \\
\hline \multicolumn{4}{|c|}{ Communal-Based Mechanisms } \\
\hline Trust & $\begin{array}{l}\text { "Confidence in an } \\
\text { exchange partner's relia- } \\
\text { bility and integrity" } \\
\text { (Morgan and Hunt } \\
\text { 1994, p. 23) }\end{array}$ & $\begin{array}{l}\text { Trust has a greater effect on per- } \\
\text { formance when environmental } \\
\text { uncertainty is higher (Guseva } \\
\text { and Rona-Tas 2001). }\end{array}$ & $\begin{array}{l}\text { Trust in large brands such as Haier } \\
\text { and Lenovo is especially effective } \\
\text { in China, where product uncer- } \\
\text { tainty is high (Cayla and Arnould } \\
\text { 2008). }\end{array}$ \\
\hline Commitment & $\begin{array}{l}\text { "An enduring desire to } \\
\text { maintain a valued rela- } \\
\text { tionship" (Moorman, } \\
\text { Zaltman, and Desh- } \\
\text { pandé 1992, p. } 316 \text { ) }\end{array}$ & $\begin{array}{l}\text { Collectivist cultures tend to } \\
\text { emphasize personal rather } \\
\text { than company-based forms of } \\
\text { commitment (Skarmeas, Kat- } \\
\text { sikeas, and Schlegelmilch } \\
\text { 2002). }\end{array}$ & $\begin{array}{l}\text { Salesperson turnover is especially } \\
\text { damaging to customer relation- } \\
\text { ships in China (Wang 2007). }\end{array}$ \\
\hline Gratitude & $\begin{array}{l}\text { "The emotional apprecia- } \\
\text { tion for benefits } \\
\text { received" (Palmatier et } \\
\text { al. } 2009, \text { p. } 1 \text { ) }\end{array}$ & $\begin{array}{l}\text { The effect of gratitude on reci- } \\
\text { procity is stronger in collec- } \\
\text { tivist cultures where customers } \\
\text { focus more on the efforts of } \\
\text { others instead of themselves } \\
\text { (Kitayama, Mesquita, and } \\
\text { Karasawa 2006). }\end{array}$ & $\begin{array}{l}\text { P\&G gave away millions of prod- } \\
\text { uct samples in Japan, where dis- } \\
\text { tributors returned the favor by } \\
\text { prominently showcasing P\&G in } \\
\text { retail locations (Kaynak and Her- } \\
\text { big 2014). }\end{array}$ \\
\hline \multicolumn{4}{|c|}{ Dynamic Mechanisms } \\
\hline Velocity & $\begin{array}{l}\text { The rate and direction of } \\
\text { change in commitment } \\
\text { (Palmatier et al. 2013) }\end{array}$ & $\begin{array}{l}\text { Relationship velocity may be } \\
\text { weaker but more stable in } \\
\text { countries with a greater long- } \\
\text { term orientation (Williams, } \\
\text { Han, and Quall 1998). }\end{array}$ & $\begin{array}{l}\text { Compared with those from Western } \\
\text { countries, customers from Japan, } \\
\text { China, and Korea exhibit slower } \\
\text { but less variable relationship } \\
\text { development (Hofstede, Jonker, } \\
\text { and Verwaart 2008). }\end{array}$ \\
\hline Resilience & $\begin{array}{l}\text { The ability to recover } \\
\text { from stressors and flexi- } \\
\text { bly adapt or even grow } \\
\text { in response to adversity } \\
\text { (Liu, Wang, and Lu } \\
\text { 2013) }\end{array}$ & $\begin{array}{l}\text { Cultures that emphasize per- } \\
\text { sonal control reduce resiliency, } \\
\text { because relationship fluctua- } \\
\text { tions, which are outside the } \\
\text { actors' control, are percieved } \\
\text { as more unfavorable and more } \\
\text { damaging to the relationship } \\
\text { (Baker, Gentry, and Rittenburg } \\
\text { 2005). }\end{array}$ & $\begin{array}{l}\text { Customers emigrating from } \\
\text { Mexico, whose culture is more } \\
\text { collectivist and deemphasizes per- } \\
\text { sonal control, maintain strong } \\
\text { relationships with multinational } \\
\text { companies, despite the disruption } \\
\text { caused by moving abroad (Broder- } \\
\text { ick et al. 2011). }\end{array}$ \\
\hline
\end{tabular}

knowledge investments (Murray and Häubl 2007), promotes repeat purchase behaviors and thus enhances seller performance, albeit through a different process. When customers invest in learning the cognitive operations associated with an LP's rules and points system, switching to a competitor becomes more challenging because customers would have to replace their previously formed knowledge with competitor-specific knowledge. Thus, for example, sellers familiar with
Delta's frequent-flyer program may shy away from learning Alaska Airline's points system, even if Alaska Airlines provides slightly more value. By creating a unique system to reward customers, sellers can create barriers to competition (Kivetz and Simonson 2003). International research has suggested that cognitive lockin is especially effective for early entrants in foreign markets. For example, Volkswagen's early-to-market loyalty-building education programs secured Chinese 
Table 2. Review of Research into International Contingency Factors

\begin{tabular}{lll}
\hline Factor & Definition & Key Findings \\
\hline
\end{tabular}

Cultural Contingency Factors

Individualism- "Extent to which people are expected to be collectivism self-reliant and distant from others (individualism) instead of mutually dependent and closely tied to others (collectivism)" (Samaha, Beck, and Palmatier 2014, p. 82; see also Hofstede, Hofstede, and Minkov 2010)

Power distance "Extent to which inequalities between more and less powerful members of society are considered acceptable" (Samaha, Beck, and Palmatier 2014, p. 83; see also Hofstede, Hofstede, and Minkov 2010)

Uncertainty avoidance

"Extent to which the members of a culture feel threatened by ambiguous or unknown situations" (Samaha, Beck, and Palmatier 2014, p. 83; see also Hofstede, Hofstede, and Minkov 2010)

Masculinity- “Degree to which 'tough' (masculine) values femininity

Long-term orientation prevail over 'tender' (feminine) values in a society" (Samaha, Beck, and Palmatier 2014, p. 83; see also Hofstede, Hofstede, and Minkov 2010)

Extent to which members of a society focus on perseverance and thrift (long-term orientation) over respect for tradition and obligations (short-term orientation) (Hofstede, Hofstede, and Minkov 2010)

\section{Developmental Contingency Factors}

Resource distribution

Degree of inequality in the income or wealth distributed among members of a society (Heshmati 2006)

Technological capital

Accumulation of capacities to invent, commercialize, and utilize technology (Avila and Evenson 2010)

Security

Freedom from or protection against physical threat (Kramer, Meyerson, and Davis 1990; Moeller and Harvey 2011; Thomas and Tow 2002)
Customers in more collectivist cultures are more motivated to maintain harmony and more persuaded by relational partners (Laroche, Kalamas, and Cleveland 2005). Thus, $\mathrm{RM}$ is more effective in more collectivist cultures (Samaha, Beck, and Palmatier 2014).

Customers in cultures with greater power distance are more likely to make social comparisons, increasing the effectiveness of status cues such as seller expertise (Pornpitakpan and Francis 2001).

Customers in cultures with greater uncertainty avoidance exhibit a stronger resistance to change and place more importance on stability (Kale and Barnes 1992; Kale and McIntyre 1991) because they are more aware of the potential risks associated with change (Deleersnyder et al. 2009).

Whereas masculine cultures deemphasize relationships in favor of competition and achievement, feminine cultures emphasize relationships and cooperation as means of achievement (Hofstede, Hofstede, and Minkov 2010; Kale and Barnes 1992; Steensma et al. 2000).

Customers in cultures with a greater long-term orientation focus more on long-term goals but are less forgiving of violations of trust, which signal short-sightedness that is incompatible with a long-term focus (Hofstede, Jonker, and Verwaart 2008).

Customers in societies with higher income inequality engage in more self-enhancement, which may increase the performance of highly visible, comparison-based loyalty rewards programs (Loughnan et al. 2011).

Technology facilitates customer relationship management efforts (Ahearne, Hughes, and Schillewaert 2007) but also can have deleterious effects on RM implementation. For example, when rapport building is expected in a service encounter, the use of technology reduces positive evaluations of the exchange (Giebelhausen et al. 2014).

Low levels of security reduce general levels of trust (Blanco and Ruiz 2013), which reduces trust in sellers overall (Grayson, Johnson, and Chen 2008). 
customers, who then became hesitant to learn about subsequent competitive entrants to their market (Frynas, Mellahi, and Pigman 2006).

Financial barriers also can enhance repeat purchase behavior and, thus, performance. Economic switching costs describe such barriers, referring to the financial losses that potentially arise when a customer transitions to a competitive seller (Jones, Mothersbaugh, and Beatty 2000). These costs can include contracts with cancellation penalties or the threatened loss of loyalty rewards (e.g., airline points) if customers fail to maintain requisite purchase activity levels or defect to a competitor. Even if sellers offer very similar LPs, economic switching costs may deter customer defection. Research has also suggested that economic switching costs are more effective in certain countries; customers in Thailand are more likely to overcome switching costs than those in Australia, for example (Patterson and Smith 2003); this tendency may stem from the stronger social support systems in more collectivist cultures such as Thailand, which reduce the personal consequences of economic risk (Mandel 2003). Overall, inertia-based mechanisms typically underlie the effects of LPs on performance and enhance customer loyalty through cuebehavior associations (habits), knowledge barriers (cognitive lock-in), and financial barriers (economic switching costs).

\section{Comparison-Based Mechanisms}

Whereas inertia-based mechanisms relate to the cognitive ease associated with duplicating previous actions, comparison-based mechanisms are social in nature and involve assessments of status or rewards relative to the status or rewards of others. These mechanisms underpin RM as well as LPs if they include special treatment or gifts (Palmatier et al. 2009; Steinhoff and Palmatier 2014). They enhance seller performance by increasing the prestige value of a current relationship or by increasing the desirability of a potential relationship through envy.

Prestige refers to respect and admiration based on achievement, success, or knowledge (Cheng et al. 2013). Loyalty programs can enhance prestige by rewarding customers for an achievement (e.g., reaching a purchase threshold) or offering them exclusivity in the form of selective access to benefits available only to customers who provide high margins (Henderson, Beck, and Palmatier 2011). Airlines reward higher-paying or frequent customers with priority boarding or upgraded seating, for example. Similarly, relationships with luxury brands may offer a form of prestige that enhances seller performance. Bufori, an Australian auto manufacturer, signals that a customer relationship with its brand constitutes an achievement and thus enhances its customers' prestige. However, this RM strategy proved unsuccessful in countries such as Malaysia that emphasize cooperation over individual achievement (De Mooij 2004). As this example highlights, the effectiveness of prestige-based LP or RM strategies can vary widely across markets, because some markets are far more prone to social comparison. In addition, an exclusive benefit that creates prestige for one customer may invoke envy in another.

Envy refers to emotional discontent resulting from an inferior position or inferior receipt of benefits relative to others (Feather and Sherman 2002). Whereas prestige likely enhances retention of the rewarded consumers, envy might increase the loyalty of excluded customers, who engage in an upward comparison with rewarded others. Envy motivates customers to improve their position by seeking the same benefits granted to others (Van de Ven, Zeelenberg, and Pieters 2009). However, if bystander customers determine that others' rewards were unearned, a type of malicious (rather than benign) envy may emerge, which can cause them to defect to competitors (Van de Ven, Zeelenberg, and Pieters 2011). In this sense, attributions largely define whether feelings of envy produce approach or avoidance motives. In international research, the positive effects of envy on purchase intentions seem to reverse in egalitarian cultures that value modesty (Watson et al. 1999). In such settings, conspicuous consumption is widely regarded as an odious process guided by ulterior, condemned, attention-seeking motives (Ferraro, Kirmani, and Matherly 2013). Such differences might explain why many customers in masculine (vs. feminine) cultures such as China, Germany, and the United Kingdom own a higher number of expensive watches (De Mooij 2004).

\section{Identity-Based Mechanisms}

Identity-based mechanisms involve "me/not me" appraisals, reflecting the attributes that people use to define their personal and social identities (Bhattacharya and Sen 2003; Brewer 1991). These identity-based mechanisms primarily define RM effectiveness because customers pursue relationships with companies as a means to express their individual characteristics (e.g., intelligence) and social affiliations (e.g., group membership) (Ahearne, Bhattacharya, and Gruen 2005). Two mechanisms are inherent to this process: in-group association and out-group dissociation. 
In-group association is the pursuit of self-connections with desired reference groups (White and Dahl 2006). Customers form stronger self-brand connections with brands that represent in-groups (Escalas and Bettman 2005); RM strategies that emphasize in-group associations therefore can enhance loyalty and word of mouth (Bhattacharya and Sen 2003). Prior research has suggested that these associations vary internationally, depending on the desirability of the in-group. For example, customers are less likely to form relationships with foreign brands in developed countries because domestic brands that symbolize their home country are more respected and desirable (De Mooij 2004). Foreign brands trying to build relationships in global markets thus tend to incorporate local symbols in their communications to increase in-group association; for example, many foreign brands use Mount Fuji in their Japanese advertisements (Keillor et al. 2011).

In contrast, out-group dissociation implies the avoidance of self-connections with undesired reference groups (White and Dahl 2006). This effect seems stronger in more independent countries, where customers have stronger self-differentiation goals (Escalas and Bettman 2005). Accordingly, RM strategies that involve partnering with undesirable reference groups can quickly result in widespread customer defection (Berger and Heath 2008), even when the out-groups are mostly favorable. For example, Chanel's famous Égoïste fragrance was deemed "too French" for U.S. customers, even though Chanel was a popular brand in the U.S. market (Curry 2009).

\section{Communal-Based Mechanisms}

Communal-based mechanisms describe the norms or rules that govern an exchange between customers and sellers (McGraw and Tetlock 2005; Mende, Bolton, and Bitner 2013). For their RM efforts, marketers often segment customers on the basis of these mechanisms, defining them as either transactional or relational (Garbarino and Johnson 1999). Prior RM research has indicated that three primary communal-based mechanisms guide relational exchanges: trust, commitment, and gratitude (Palmatier et al. 2009).

Trust is "confidence in an exchange partner's reliability and integrity" (Morgan and Hunt 1994, p. 23). It enhances the seller's performance by lowering transaction costs, and it reflects the firm's size, salespeople, expertise, and likeability (Doney and Cannon 1997). International research has suggested that trust is more effective for reducing transaction costs and increasing performance in countries with more uncertain markets or industries (Grayson, Johnson, and Chen 2008; Guseva and Rona-Tas 2001). Accordingly, the trustworthy reputation of large firms historically has been especially important in emerging economies such as Brazil or China (Cayla and Arnould 2008).

Commitment, which can arise from trust (Morgan and Hunt 1994), is "an enduring desire to maintain a valued relationship" (Moorman, Zaltman, and Deshpandé 1992, p. 316). Commitment builds over time based on perceptions of relationship value, and it enhances performance by increasing intentions to remain loyal to (i.e., repurchase from) a seller (Johnson, Herrmann, and Huber 2006). International research has suggested that the effect of commitment on seller performance is moderated by cultural dimensions. For example, commitment exerts a stronger effect in cultures that tend to value status hierarchies and emphasize the importance of allegiance (Samaha, Beck, and Palmatier 2014). Culture also shapes the target of commitment: people in cultures that emphasize interpersonal relationships tend to exhibit commitment toward salespeople rather than companies (Skarmeas, Katsikeas, and Schlegelmilch 2002). Thus, salesperson turnover harms customer commitment in collectivist countries such as China (Wang 2007).

Gratitude, or "emotional appreciation for benefits received" (Palmatier et al. 2009, p. 1), operates alongside trust and commitment and also can have a direct effect on commitment. Gratitude is a prosocial emotion that enhances the performance of high-effort sellers by increasing their favorable attitudes and retention (Morales 2005). The positive effects of gratitude are stronger in collectivist cultures, where customers focus more on the efforts of others than of themselves (Kitayama, Mesquita, and Karasawa 2006). This trend may explain the success of Procter \& Gamble's (P\&G's) RM initiative to give away millions of product samples as gifts in Japan, where distributors reciprocated the favor by prominently showcasing $P \& G$ in their retail locations (Kaynak and Herbig 2014). Overall, trust, commitment, and gratitude constitute communal-based mechanisms that shape the norms that govern exchanges, thereby enhancing seller performance.

\section{DYNAMIC MECHANISMS}

Finally, communal-based mechanisms develop dynamically (Palmatier et al. 2013), so a full understanding of $\mathrm{RM}$ effectiveness demands consideration of the dynamic 
mechanisms that regulate relationship development. However, research on dynamic mechanisms remains relatively nascent partly because of methodological obstacles (Luo and Kumar 2013). Early research examined relational mechanisms at various life cycle stages (Jap 2001); more recent studies consider change as a construct itself. Two dynamic mechanisms have emerged from these approaches: velocity and resiliency.

Velocity is the rate and direction of change in commitment (Palmatier et al. 2013) driven by trust, communication, and investments. It offers a better predictor of performance than the level of commitment because customers base their decisions more on relational trends than on their current states (Palmatier et al. 2013). In addition, relationship velocity may be weaker but more stable in countries with a stronger long-term orientation because, in these settings, relationships develop over a longer time horizon (Williams, Han, and Qualls 1998). Thus, compared with buyers in Western countries, customers from Japan, China, and Korea tend to exhibit slower but less variable relationship development over time (Hofstede, Jonker, and Verwaart 2008).

Alternatively, resilience refers to the ability to recover effectively from stressors and then flexibly adapt or even grow in response to adversity (Liu, Wang, and $\mathrm{Lu}$ 2013). Research on resilience as it relates to RM is scarce, but social psychology studies of interpersonal relationships have indicated its key role in predicting long-term relationship persistence. When partners can overcome fluctuations in commitment over time, they are more likely to maintain a relationship (Arriaga et al. 2006). International research on resilience has suggested that cultures that emphasize personal control suffer lower resilience because relationship fluctuations, which are outside the actors' control, are perceived as less favorable and thus more damaging to the relationship (Baker, Gentry, and Rittenburg 2005). As an illustration, emigrants from Mexico, a more collectivist culture that deemphasizes personal control (Hofstede, Hofstede, and Minkov 2010), often maintain strong relationships with multinational companies, despite the disruption caused by their move abroad (Broderick et al. 2011).

Overall, we thus contend that the mechanisms underlying the effectiveness of RM and LPs can be categorized thematically: inertia-based mechanisms (habit, cognitive lock-in, and economic switching costs) enhance seller performance by increasing cognitive ease through the repetition of previous action; comparison-based mechanisms (prestige and envy) do so by affixing feelings of prestige and envy to otherwise routine purchases; identity-based mechanisms (in-group association and outgroup dissociation) enhance seller performance if their products or services help define customers' identities; communal-based mechanisms (commitment, trust, and gratitude) benefit sellers by altering the norms that govern exchanges; and dynamic mechanisms (velocity and resiliency) enhance seller performance by shifting the levels of the communal-based mechanisms over time. We consider next how and why each of these performance-enhancing mechanisms should be leveraged across global markets.

\section{HOW RM AND LP EFFECTIVENESS VARY GLOBALLY}

To understand how the effectiveness of RM and LP mechanisms vary globally, we begin by reviewing the cultural and developmental contingency factors, outlined in Table 2, that distinguish global markets. Then we offer predictions about how these factors might moderate the effects of RM and LP mechanisms on seller performance. Culture describes the configuration of values, norms, and expectations that influence how members in a society process information and experience emotions (Hofstede and Minkov 2010; Kitayama, Mesquita, and Karasawa 2006; Samaha, Beck, and Palmatier 2014; Steenkamp and De Jong 2010). We adopt Hofstede's five-factor model of culture to describe how cultural contingency factors might moderate the effectiveness of RM and LPs (Hofstede and Minkov 2010). Development instead refers to the relative economic progress and capital accumulation that characterizes global markets (Ellis 2003; Heshmati 2006). Whereas culture ripens over centuries and is passed on from generation to generation, economic development features punctuate growth and can vary sharply, even between countries with very similar cultures (Hofstede, Hofstede, and Minkov 2010; Piketty 2014). We present three developmental contingency factors derived from our review of international research, after considering culture.

\section{Moderating Role of Cultural Contingency Factors}

Individualism-Collectivism. The individualism-collectivism cultural contingency factor captures the "extent to which people are expected to be self-reliant and distant from others (individualism) instead of mutually dependent and closely tied to others (collectivism)" (Samaha, Beck, and Palmatier 2014, p. 82; see also Hofstede, Hofstede, and 
Minkov 2010). Previous research has demonstrated that RM mechanisms such as trust and commitment are more effective in societies with more collectivist cultural values (Samaha, Beck, and Palmatier 2014), possibly because collectivism enhances the importance of in-groups and instills beliefs that relationships should be mutually rather than personally beneficial (Steensma et al. 2000). Customers in collectivist cultures also are more concerned with maintaining relationship harmony and thus more persuaded by relational partners (Laroche, Kalamas, and Cleveland 2005).

In line with the greater importance of close relationships and concerns for relational harmony, we expect that higher levels of collectivism increase the effectiveness of identity-based and communal-based RM and LP mechanisms because customers in more collectivist cultures focus more on the importance of relationships and the significance of in-group identity (Hofstede, Hofstede, and Minkov 2010). As collectivism increases, the markers of group identity provided by LPs should satisfy customers' stronger in-group identification motives. The evidence of LP successes and failures worldwide supports this prediction. For example, membership cards increase purchase behaviors more effectively in more collectivist countries (e.g., Singapore) than in more independent countries (e.g., the Netherlands) (Noordhoff, Pauwels, and Odekerken-Schröder 2004). Furthermore, consumers in more collectivist cultures should be more responsive to communal norms that regulate relationships and promote reciprocity in the form of greater loyalty (Samaha, Beck, and Palmatier 2014); this rationale may explain why Japanese customers were quick to reciprocate P\&G's gift campaign, in that Japan is characterized by relatively high collectivism (Hofstede, Hofstede, and Minkov 2010; Kaynak and Herbig 2014). We therefore predict the following:

$\mathrm{P}_{1}$ : As cultural collectivism increases, (a) identityand (b) communal-based mechanisms exert stronger effects on seller performance.

Power Distance. The power distance cultural contingency factor captures the "extent to which inequalities between more and less powerful members of society are considered acceptable" (Samaha, Beck, and Palmatier 2014 , p. 83). Greater power distance increases people's focus on social rank because they view society in terms of hierarchies and social roles (Hofstede, Hofstede, and Minkov 2010). Customers in cultures with greater power distance therefore may be more likely to make social comparisons, which should increase customer reactions to cues that suggest differences in ranking or status (Pornpitakpan and Francis 2000). Comparisonbased RM and LP mechanisms-such as prestige and envy that arise from receiving exclusive treatment or observing its conferral on others (Steinhoff and Palmatier 2014) or from relationships maintained with luxury brands (De Mooij 2004)-thus should have stronger effects on seller performance in cultures marked by greater power distance because customers in these cultures likely compare their rewards with the rewards received by others or their exchange relationships against the exchange relationships maintained with others. This prediction is congruent with recent evidence of the effectiveness of status-based marketing in high-power-distance markets such as China, where customers exhibit stronger preferences for exclusivity and status-based exchange relationships (Atsmon et al. 2012). Thus, we predict the following:

\section{$\mathrm{P}_{2}$ : As cultural power distance increases, comparison- based mechanisms exert stronger effects on seller performance.}

Uncertainty Avoidance. The uncertainty avoidance cultural contingency factor captures the "extent to which the members of a culture feel threatened by ambiguous or unknown situations" (Samaha, Beck, and Palmatier 2014 , p. 83). Previous research has demonstrated that products diffuse more slowly in cultures marked by greater uncertainty avoidance (Tellis, Stremersch, and Yin 2003), because uncertainty avoidance increases people's resistance to change and simultaneously increases the importance they assign to stability (Kale and Barnes 1992; Kale and McIntyre 1991). Customers in cultures with higher uncertainty avoidance are more aware of the potential risks associated with change (Deleersnyder et al. 2009). Therefore, as uncertainty avoidance increases, inertia-based mechanisms that enhance seller performance by increasing the relative advantage of previous behaviors should be even more effective. The risks associated with changing their behaviors are highly salient among customers in uncertaintyavoidant cultures, making them less likely to stray from their previous behaviors. That is, customers in these cultures should be more likely to rely on habits or previously learned knowledge because breaking those habits or learning about a new company's policies and procedures seems riskier. A customer survey by Garcia, Lacayo, and Martinze (2012) offers evidence in support of this prediction. The authors find that fewer than $2 \%$ of Mexican customers (vs. $11 \%$ of U.S. customers) switched to lower-cost food brands in the previous 12 months. The stronger effects of prior purchasing habits in Mexico (vs. the United States) may be explained by 
Mexico's much greater uncertainty avoidance (Hofstede, Hofstede, and Minkov 2010).

$\mathrm{P}_{3}$ : As uncertainty avoidance increases, inertiabased mechanisms exert stronger effects on seller performance.

Masculinity-Femininity. The masculinity-femininity cultural contingency factor captures the "degree to which 'tough' (masculine) values prevail over 'tender' (feminine) values in a society" (Samaha, Beck, and Palmatier 2014, p. 83). Whereas masculine cultures deemphasize relationships in favor of competition and achievement, feminine cultures emphasize relationships and cooperation as means for achievement (Hofstede, Hofstede, and Minkov 2010; Kale and Barnes 1992; Steensma et al. 2000). Customers in more feminine cultures thus are more likely to help strangers, in an effort to build relationships (Lam, Lee, and Mizerski 2009). Consistent with the intense affiliation focus in more feminine cultures, we expect that as cultural masculinity increases, the effectiveness of communal-based RM and LP mechanisms (trust and commitment) diminish. Furthermore, the emphasis on competition in more masculine cultures may accentuate the effects of comparisonbased mechanisms (prestige and envy) because competition naturally increases social comparisons (Gibbons and Buunk 1999). Thus, for example, customers try to build relationships with high-status automotive brands, which increase prestige and invoke envy, more in masculine cultures such as Germany and less in feminine cultures such as the Netherlands (De Mooij 2000; Hofstede, Hofstede, and Minkov 2010). Thus, we predict the following:

$\mathrm{P}_{4 \mathrm{a}}$ : As cultural masculinity increases, communalbased mechanisms exert weaker effects on seller performance.

$\mathrm{P}_{4 \mathrm{~b}}$ : As cultural masculinity increases, comparisonbased mechanisms exert stronger effects on seller performance.

Long-Term Orientation. The long-term orientation cultural contingency factor captures the extent to which members of a society focus on perseverance and thrift (long-term orientation) rather than respect for tradition or obligations (short-term orientation) (Hofstede, Hofstede, and Minkov 2010). Customers in cultures with a stronger long-term orientation focus more on long-term goals but are less forgiving of violations of trust because such violations signal a short-sightedness that is incompatible with a long-term focus (Hofstede, Jonker, and Verwaart 2008). Therefore, we expect a long-term ori- entation to moderate the effectiveness of inertia-based and dynamic mechanisms. Specifically, customers with a longer-term goal focus should be more likely to implement their intentions to override inertia-based mechanisms such as habit (Wood and Neal 2009); prior behaviors should have less bearing on present behaviors when customers focus more on the future. Customers with a long-term orientation also are more likely to change their spending habits and make long-term investments (Howlett, Kees, and Kemp 2008), so we similarly expect that they might change their routine purchase behaviors, despite the incentives of loyalty rewards, to achieve their personal goals. Therefore, inertia-based mechanisms should be weaker in cultures with a stronger long-term orientation. In addition, dynamic mechanisms such as velocity and resilience should be less effective as longterm orientation increases. This is because violations of trust or commitment, which naturally arise in any relationship, are more damaging in cultures with stronger long-term orientation, which should make relationships grow more slowly. These predictions are consistent with findings that customers in Eastern cultures, which have stronger long-term orientations, are slower to develop relationships (Hofstede, Jonker, and Verwaart 2008). We therefore predict the following:

$\mathrm{P}_{5}$ : As long-term orientation increases, (a) inertiabased and (b) dynamic mechanisms exert weaker effects on seller performance.

\section{Moderating Role of Developmental Contingency Factors}

A society's culture develops and endures over centuries (Hofstede, Hofstede, and Minkov 2010); its economic development is a more short-term feature. Since the Industrial Revolution, economics and social welfare scholars have classified countries on the basis of how their development compares with that of their neighbors (Piketty 2014; Schumpeter 1934). In marketing, despite substantial investigations of the role of culture (Steenkamp 2001), less attention has focused on developmental factors. This oversight may be significant because economic development influences markets and can be orthogonal to culture (Henrich et al. 2010). For example, despite the relative cultural similarity between Iran and Saudi Arabia (Hofstede, Hofstede, and Minkov 2010), the per capita gross domestic product of Iran is one-fifth that of Saudi Arabia (World Bank 2014). We thus consider three developmental contingency factors, derived from comparative international frameworks that may influence the effectiveness of RM and LPs: resource distribution, technological capital, and security. 
Resource Distribution. This developmental contingency factor captures the degree of inequality in the income or wealth distributed among members of a society (Heshmati 2006). Distribution inequality relates quadratically to economic development, such that the greatest inequality occurs at moderate levels of economic development (Chen 2003; Kuznets 1955). Greater distribution inequality reduces the general level of trust in a society, especially among low earners, because they view the world as less fair; in addition, communities become more divided (Oishi, Kesebir, and Diener 2011). Thus, as resource distributions become more unequal, communal-based RM and LP mechanisms such as trust and commitment should have stronger effects on seller performance because rare, trust-based relationships grow more notable, important, and effective (Guseva and Rona-Tas 2001). Thus, for example, customer trust and commitment have twice the effect on seller performance in Brazil compared with Norway (Samaha, Beck, and Palmatier 2014) possibly because resource distributions in Brazil are twice as unequal as those of Norway (World Bank 2014). Greater resource inequality also reduces customers' satisfaction with their level of possessions because they note wider possession gaps with wealthier customers (Ordabayeva and Chandon 2011). Accordingly, customers in countries with greater resource inequality engage in more self-enhancement (Loughnan et al. 2011). We predict that the wider possession gaps that characterize societies with greater distribution inequality increase the effectiveness of RM and LP comparison-based mechanisms because customers try to "keep up with the Joneses" by forming relationships with more prestigious companies (Ordabayeva and Chandon 2011) or signaling their status with exclusive loyalty rewards (Steinhoff and Palmatier 2014). That is, we predict the following:

$\mathrm{P}_{6}$ : As resource distribution becomes more unequal, (a) communal-based and (b) comparison-based mechanisms exert stronger effects on seller performance.

Technological Capital. Defined as the accumulation of capacities to invent, commercialize, and exploit innovative technologies (Bell and Pavitt 1997; Robertson and Gatignon 1986), technological capital correlates with economic development. Specifically, greater market integration and competition enhance the opportunities for sellers in a society to develop and use technologies (Bustos 2011; Guillén and Suárez 2005). If the country possesses higher levels of technological capital, sellers also are more likely to use technology to facilitate their customer relationship management (Payne and Frow
2005). These expanded RM tactics may lead customers in these countries to become acclimated to sellers' constant attempts to build trust and commitment, such that they no longer respond to most sellers' RM attempts (The Economist 2014). Previous findings indicate that RM strategies are more effective for firstmovers that implement the strategies before their competitors (Kumar et al. 2011). Thus, difficult-to-form customer relationships, once formed, should be more valuable to sellers in countries with greater technological capital. That is, existing levels of trust, commitment, and gratitude (communal-based mechanisms) should be more effective in countries with higher levels of technological capital because customers learn to ignore competitors' attempts to build relationships, rendering these efforts less effective.

A similar prediction arises for the effectiveness of inertiabased mechanisms. Customers in societies with higher levels of technological capital are continually bombarded with LP offers (Ferguson and Hlavinka 2007), many of which involve complicated accrual and redemption rules (Henderson, Beck, and Palmatier 2011). As technological capital increases, we anticipate greater competition among LPs, each with specific rules that customers must learn, such that the likelihood that customers seek out novel LPs may decrease. The inertiabased mechanisms therefore may be more effective in cultures with greater technological capital because customers are less likely to stray from their previous behaviors. The tendency for technology to create a narrowed focus is particularly evident in studies of telecommunications: Internet expansion has made more information more readily available to users, but people are less likely to seek out or receive exposures to unfamiliar information as the web increases in complexity (Pariser 2011). Increased variety also can cause consumers to feel overwhelmed, such that they simply stick with what they know. Accordingly, customer habits are receiving increasing research attention in countries with high technological accumulation (Marketing Science Institute 2014; Shah, Kumar, and Kim 2014), possibly out of recognition that customers in these societies find it more difficult to overcome entrenched behaviors. In summary, we expect the following:

$\mathrm{P}_{7}$ : As level of technological capital increases, (a) communal-based and (b) inertia-based mechanisms exert stronger effects on seller performance.

Security. Finally, security refers to freedom from or protection against physical threat (Kramer, Meyerson, and 
Davis 1990; Moeller and Harvey 2011; Thomas and Tow 2002). It might be provided by formal institutions (e.g., police force) or greater social capital, defined as "the information, trust, and norms of reciprocity inhering in one's social networks" (Woolcock 1998, p. 153). As societies develop and become more integrated in global markets, institutions and social norms evolve in ways that tend to increase overall security (Henrich et al. 2010). The association between development and security is so fundamental that even the dilapidation of physical structures can reduce people's perceptions of security (O'Brien and Wilson 2011). Low levels of security in turn invoke several key effects for customers. First, insecurity reduces institutional trust (Blanco and Ruiz 2013), which may make it more difficult for sellers to build trust among customers (Grayson, Johnson, and Chen 2008). Second, insecurity reduces perceptions of personal power, which subsequently amplify the effects of disorder on mistrust (Ross, Mirowsky, and Pribesh 2001). That is, insecurity creates a vicious cycle of mistrust. Third, insecurity can cause fear, which prompts coping responses (Sternthal and Craig 1974), such as becoming more emotionally attached to familiar brands (Dunn and Hoegg 2014). Customers experiencing fear also may become anxious (Keller and Block 1996) and engage in regulatory processes to reduce these unpleasant feelings, which can lead to fatigue or psychological depletion (Gailliot, Schmeichel, and Baumeister 2006).

Drawing on these findings, we offer several predictions about how security should influence the effectiveness of RM and LP mechanisms. Because insecurity reduces the availability of psychological resources needed to change behaviors (Muraven and Baumeister 2000), we predict that lower levels of security increase the effectiveness of inertia-based mechanisms. In other words, customers who experience low levels of security and expend cognitive and emotional resources to cope with that insecurity should be more likely to rely on their prior behaviors when making decisions, which would increase the effectiveness of habits or cognitive lock-in created by LPs. Because insecurity also reduces trust, we expect that lower levels of security increase the efficacy of trust and commitment toward current sellers. This prediction is similar to $\mathrm{P}_{6 \mathrm{a}}$, in which we argue that lower levels of general trust make existing relationships more valuable. Thus we anticipate the following:

$\mathrm{P}_{8}$ : As the level of security increases, (a) inertiabased and (b) communal-based mechanisms exert weaker effects on seller performance.

\section{DISCUSSION}

Relationship marketing and LPs are potent strategies for increasing seller differentiation and enhancing retention (Palmatier et al. 2006; Stahl et al. 2012). Recent increases in international competition have prompted an expansion of global interest in RM and LPs, though researchers still tend to apply U.S.-based frameworks abroad (Samaha, Beck, and Palmatier 2014). To understand the potential for international differences in RM and LP effectiveness, this review proposes a comprehensive framework of the multiple mechanisms that underlie RM and LPs, as well as how each mechanism may be moderated by multiple cultural and developmental contingency factors. As a product of this effort, we offer 8 propositions (comprising 14 predictions overall) about how the effect of each RM and LP mechanism might be leveraged in international markets. Table 3 contains a summary of these predictions.

Our propositions provide key directions for managers aiming to tailor their RM and LP strategies to appeal to a specific culture. What adjustments should a manager make to the structure of an LP or RM strategy to succeed in a different culture? Our review of the mechanisms that underlie RM and LPs outlines the determinants of success for various RM or LP strategies. We also use cultural factors to extend these findings and propose more appropriate circumstances for emphasizing certain mechanisms. That is, our eight proposals leverage prior findings about different aspects of culture, apply these findings to the RM and LP domains, and identify unique cultural circumstances in which specific RM or LP mechanisms should be particularly beneficial. For example, a hierarchical LP that activates status needs should be more successful in a masculine culture because it invokes comparison-based mechanisms that appeal to members of highly masculine cultures $\left(\mathrm{P}_{4 \mathrm{~b}}\right)$. However, implementing the same LP in a highly feminine culture, without adjusting its structure, may result in less success because these latter cultures are less likely to respond to prestige or envy mechanisms; instead, they likely respond better to communalbased mechanisms such as trust and commitment.

In addition, the interaction of developmental contingency factors with RM and LP mechanisms can be critical to the strategy's success. In countries with severe resource inequality, for example, communal-based RM mechanisms should have substantial effects on seller performance, so establishing a strong reputation and gaining consumer trust may be a higher priority. Furthermore, these effects may be additionally strengthened when cultural feminism is higher. This example 
Table 3. Summary of Predictions

\begin{tabular}{|c|c|c|c|}
\hline $\begin{array}{l}\text { General } \\
\text { Mechanisms }\end{array}$ & Specific Constructs & Leveraging Factors (Direction) & Propositions \\
\hline $\begin{array}{l}\text { Inertia-based } \\
\text { mechanisms }\end{array}$ & $\begin{array}{l}\text { Habit, cognitive lock-in, eco- } \\
\text { nomic switching costs }\end{array}$ & $\begin{array}{l}\text { Uncertainty avoidance }(+) \text {, long-term orientation } \\
(-) \text {, technological capital }(+) \text {, security }(-)\end{array}$ & $\mathrm{P}_{3}, \mathrm{P}_{5 \mathrm{a}}, \mathrm{P}_{7 \mathrm{~b}}, \mathrm{P}_{8 \mathrm{a}}$ \\
\hline $\begin{array}{l}\text { Comparison-based } \\
\text { mechanisms }\end{array}$ & Prestige, envy & $\begin{array}{l}\text { Power distance }(+) \text {, masculinity }(+) \text {, resource } \\
\text { inequality }(+)\end{array}$ & $\mathrm{P}_{2}, \mathrm{P}_{4 \mathrm{~b}}, \mathrm{P}_{6 \mathrm{~b}}$ \\
\hline $\begin{array}{l}\text { Identity-based } \\
\text { mechanisms }\end{array}$ & $\begin{array}{l}\text { In-group association, out- } \\
\text { group dissociation }\end{array}$ & Collectivism (+) & $\mathrm{P}_{1 \mathrm{a}}$ \\
\hline $\begin{array}{l}\text { Communal-based } \\
\text { mechanisms }\end{array}$ & $\begin{array}{l}\text { Trust, commitment, } \\
\text { gratitude }\end{array}$ & $\begin{array}{l}\text { Collectivism }(+) \text {, masculinitiy }(-) \text {, resource } \\
\text { inequality }(+) \text {, technological capital }(+) \text {, security } \\
(-)\end{array}$ & $\mathrm{P}_{1 \mathrm{~b}}, \mathrm{P}_{4 \mathrm{a}}, \mathrm{P}_{6 \mathrm{a}}, \mathrm{P}_{7 \mathrm{a}}, \mathrm{P}_{8 \mathrm{~b}}$ \\
\hline $\begin{array}{l}\text { Dynamic } \\
\text { mechanisms }\end{array}$ & Velocity, resilience & Long-term orientation (-) & $\mathrm{P}_{5 \mathrm{~b}}$ \\
\hline
\end{tabular}

would suggest that communal-based RM mechanisms are especially effective in many South American countries such as Chile, Costa Rica, and Guatemala, where inequality and cultural feminism is relatively high. In other words, RM strategies that enhance trust and commitment (e.g., communication, expertise, relationship benefits; Palmatier et al. 2006) may be most effective in these countries.

Overall, we offer 14 testable propositions for further research. Testing individual propositions across countries may prove challenging, but recent efforts, such as meta-analyses that incorporate country-level information about samples to test country-level moderating effects (Samaha, Beck, and Palmatier 2014), have demonstrated that such research is feasible. In addition, we consider several approaches for building on our proposed framework.

\section{Future Research Directions}

This review bridges theory across multiple disciplines to shed light on how RM and LP strategies should be adapted internationally. In addition to offering multiple propositions, the framework presented in this review is a springboard for further research. For example, we only considered moderation effects that were clearly supported by extant theory, but as the many theories drawn on in this research are refined and expanded, new moderation predictions will likely emerge. In addition, we only consider performance as a key outcome, but other outcomes (e.g., word of mouth) may also be affected. Moreover, future studies may extend the framework presented in this review in several key ways, which we outline in detail next.

Delineating RM and LPs. Relationship marketing and LP research has largely ignored key similarities and differences between RM and LP strategies. If the goal of an LP is to build or maintain customer relationships, it can be categorized as an RM strategy. However, this goal is not always central, so LP research is distinct from the RM domain. In this review, we sorted the thematically categorized mechanisms according to their relevance to either LP or RM research, in an effort to help clarify the overlap between these domains. For example, inertiabased mechanisms primarily affect LPs, often beyond the scope of RM, whereas identity-based, communalbased, and dynamic mechanisms primarily affect RM and relationship-oriented LPs. Comparison-based mechanisms affect both RMs and LPs, as long as the LP involves rewards or special treatment. These insights are helpful, and yet there is also benefit in studying RM and LPs separately. For example, the overlap between RM and LP mechanisms suggests the need to consider interactions between the mechanisms that underlie both concepts, such as the relationship between habit as an inertia-based mechanism and commitment as a communal-based mechanism. Further research might consider ways in which LPs give rise to mechanisms that leverage RM to understand how LPs can complement rather than simply serve as RM strategies. 
Examining the Dark Side of RM and LPs. Future studies should also consider how the negative aspects of RM and LP strategies vary internationally. For example, unrewarded customers who observe dispensation of loyalty rewards to others are one key example of a negative effect of relationship-orientated LPs, in which LP strategies have unintended consequences on observing customers. More specifically, a hierarchically structured LP that gives highly ranked members visible, special treatment above members who are lower on the hierarchy may cause these lower-ranked members to feel extreme envy (Steinhoff and Palmatier 2014). This effect may be greater in egalitarian cultures, where customers are less likely to respond to status signals (Kim and Zhang 2014), or in feminine cultures, where customers are more concerned about the needs of others (Hofstede 1998).

In addition, as relationships age, levels of commitment may decrease, increasing the chance for opportunism to occur after trust has been established (Moorman, Zaltman, and Deshpandé 2008). This negative effect has the potential to be particularly destructive in collectivist cultures, where communal mechanisms are predicted to have a stronger effect. Furthermore, this type of opportunism and disregard for the history of the relationship may be more likely in individualistic cultures and cultures without a long-term orientation because shortterm-oriented cultures may be more preoccupied with outcomes related to the immediate future rather than relying on the implied long-term outcomes of any established relationship. Members of individualistic cultures may similarly be distracted from the well-being of others or the relationship itself in favor of concern for their individual well-being.

Furthermore, in relationships, customers often feel pressure to return a favor or kindness. This "norm of reciprocity" (Palmatier et al. 2009; Perugini et al. 2003) may lead to a trade-off situation in which the costs of reciprocation outweigh the benefits of continuing the relationship. Feminine cultures, collectivist cultures, and long-term-oriented cultures are predicted to be more sensitive to this norm. Masculine cultures, individualistic cultures, and cultures with a shorter-term orientation may be more likely to break off a relationship because of the high costs of reciprocation.

Evaluating Exchange Context. Further research may also consider how the proposed effects of the mechanisms and contingency factors vary contextually. For example, we expect identity- and communal-based mechanisms to be especially effective in more collectivist cultures. These effects may further vary across businessto-consumer versus business-to-business markets, as business-to-consumer customers consider their peer groups more when making purchase decisions (Hofstede, Hofstede, and Minkov 2010). In addition, the effects of inertia- and communal-based mechanisms may also vary depending on whether a firm is selling a service or a product. Services are becoming increasingly experience-centric, which usually implies an emotionally engaging relationship between the consumer and the service provider (Voss, Roth, and Chase 2008). The importance of communal-based mechanisms in service contexts suggests that the moderating effects of contingency factors may be strongest when service levels are high (vs. low). Prior research has identified many additional business contexts (e.g., channel vs. direct, exchange with an individual vs. organization; Palmatier et al. 2006) that future researchers might consider as further moderating the effects proposed by our model.

Expanding International Frameworks. Current international research on RM and LPs has examined cultural differences extensively but has largely failed to consider economic development, despite its direct influence on markets and variance across cultures. Similar cultures might react in entirely different ways to the same RM and LP strategies; we posit that developmental contingency factors explain some of these differences. The three developmental contingency factors that we identify in this study should serve as starting points for continued research into the impact of economic development on RM and LP outcomes. Researchers should particularly consider their interaction with cultural factors, in that developmental contingency factors may have significant psychological consequences that likely vary alongside cultural factors and thus indirectly shape the effectiveness of RM and LPs. Finally, additional research should investigate which factors (cultural or developmental contingency) exert stronger effects on RM and LP effectiveness, as well as the circumstances in which one type might be more influential than another.

Examining Contingency-Level Interactions. Finally, further research may consider interactions among cultural and developmental contingency factors. For example, high levels of resource inequality may accentuate the effects of power distance. Previously, we posited that comparison-based mechanisms would have stronger effects in countries with greater cultural power distance. These effects may be further enhanced when economic inequality is high (vs. low). In other words, when values match economic realities, customers may 
be even more likely to seek rewards that suggest higher social rank.

\section{Conclusion}

Our review assimilates current RM and LP research and links it to findings on culture and economic development. We list multiple mechanisms that underpin RM and LPs, categorize them thematically, discuss the moderating roles of cultural factors and developmental contingency factors, and outline eight resultant propositions that contribute to extant literature and offer managerial implications. Researchers should continue to investigate the relationship between cultural factors and developmental contingency factors; research on RM and LPs would also benefit from a focus on the interactions of their respective mechanisms as well as a greater consideration of the dynamic aspect of communal mechanisms. Overall, this study broadens the scope of global research on RM and LPs and contributes to prior literature by delineating RM and LP research, such that it provides a clear framework for further investigations.

\section{REFERENCES}

Ahearne, Michael, C.B. Bhattacharya, and Thomas Gruen (2005), "Antecedents and Consequences of Customer-Company Identification: Expanding the Role of Relationship Marketing," Journal of Applied Psychology, 90 (3), 574-85.

, Douglas E. Hughes, and Niels Schillewaert (2007), "Why Sales Reps Should Welcome Information Technology: Measuring the Impact of CRM-Based IT on Sales Effectiveness," International Journal of Research in Marketing, 24 (4), $336-49$.

Arriaga, Ximena B., Jason T. Reed, Wind Goodfriend, and Christopher R. Agnew (2006), "Relationship Perceptions and Persistence: Do Fluctuations in Perceived Partner Commitment Undermine Dating Relationships?” Journal of Personality and Social Psychology, 91 (6), 1045-65.

Atsmon, Yuval, Diane Ducarme, Max Magni, and Cathy Wu (2012), "Luxury Without Borders: China's New Class of Shoppers Take on the World," research report, McKinsey Consumer \& Shopper Insights, (December), (accessed July 1, 2015), [available at https://solutions.mckinsey.com/insightschina/default/ en-us/about/our_publications.aspx ]

Avila, Antonio Flavio Dias and Robert E. Evenson (2010), "Total Factor Productivity Growth in Agriculture: The Role of Technology Capital," in Handbook of Agricultural Economics, Vol. 4, Prabhu L. Pingali and Robert E. Evenson, eds. Amsterdam: Elsevier, 3769-3822.
Baker, Stacey Menzel, James W. Gentry, and Terri L. Rittenburg (2005), "Building Understanding of the Domain of Consumer Vulnerability,” Journal of Macromarketing, 25 (2), 128-39.

Batra, Rajeev, Venkatram Ramaswamy, Dana L. Alden, JanBenedict E.M. Steenkamp, and S. Ramachander (2000), "Effects of Brand Local and Nonlocal Origin on Consumer Attitudes in Developing Countries," Journal of Consumer Psychology, 9 (2), 83-95.

Bell, Martin and Keith Pavitt (1997), "Technological Accumulation and Industrial Growth: Contrasts Between Developed and Developing Countries," Technology, Globalisation and Economic Performance, 2 (1), 83-137.

Berger, Jonah and Chip Heath (2008), "Who Drives Divergence? Identity Signaling, Outgroup Dissimilarity, and the Abandonment of Cultural Tastes," Journal of Personality and Social Psychology, 95 (3), 593-607.

Bhattacharya, C.B. and Sankar Sen (2003), "Consumer-Company Identification: A Framework for Understanding Consumers' Relationships with Companies," Journal of Marketing, 67 (April), 76-88.

Blanco, Luisa and Isabel Ruiz (2013), "The Impact of Crime and Insecurity on Trust in Democracy and Institutions," American Economic Review, 103 (3), 284-88.

Brewer, M. (1991), "The Social Self: On Being the Same and Different at the Same Time," Personality and Social Psychology Bulletin, 17 (5), 475-82.

Broderick, Amanda J., Catherine Demangeot, Natalie Ross Adkins, Nakeisha S. Ferguson, Geraldine Rosa Henderson, Guillaume Johnson, et al. (2011), "Consumer Empowerment in Multicultural Marketplaces: Navigating Multicultural Identities to Reduce Consumer Vulnerability," Journal of Research for Consumers, 19 (Special Section Part 1), 1-13.

Bustos, Paula (2011), “Trade Liberalization, Exports, and Technology Upgrading: Evidence on the Impact of MERCOSUR on Argentinian Firms," American Economic Review, 101 (1), 304-340.

Carvalho, Sergio W. (2004), “Assessing the Role of Nationalistic Feelings in Consumers' Willingness to Take Action Against Foreign Products: An Exploratory Study in Brazil," Latin American Business Review, 4 (2), 21-35.

Cayla, Julien and Eric J. Arnould (2008), “A Cultural Approach to Branding in the Global Marketplace," Journal of International Marketing, 16 (4), 86-112.

Chen, Been-Lon (2003), “An Inverted-U Relationship Between Inequality and Long-Run Growth," Economics Letters, 78 (2), 205-212.

Cheng, Joey T., Jessica L. Tracy, Tom Foulsham, Alan Kingstone, and Joseph Henrich (2013), "Two Ways to the Top: 
Evidence That Dominance and Prestige Are Distinct Yet Viable Avenues to Social Rank and Influence," Journal of Personality and Social Psychology, 104 (1), 103-125.

Curry, Jeffrey E. (2009), A Short Course in International Marketing. Petaluma, CA: World Trade Press.

Deleersnyder, Barbara, Marnik G. Dekimpe, Jan-Benedict E.M. Steenkamp, and Peter S.H. Leeflang (2009), "The Role of National Culture in Advertising's Sensitivity to Business Cycles: An Investigation Across Continents," Journal of Marketing Research, 46 (October), 623-36.

De Mooij, Marieke (2000), “The Future Is Predictable for International Marketers: Converging Incomes Lead to Diverging Consumer Behavior," International Marketing Review, 17 (2), 103-113.

(2004), Consumer Behavior and Culture: Consequences for Global Marketing and Advertising. Thousand Oaks, CA: Sage Publications.

Doney, Patricia M. and Joseph P. Cannon (1997), "An Examination of the Nature of Trust in Buyer-Seller Relationships," Journal of Marketing, 61 (April), 35-51.

Dunn, Lea and JoAndrea Hoegg (2014), "The Impact of Fear on Emotional Brand Attachment," Journal of Consumer Research, 41 (1), 152-68.

The Economist (2004), "But Can You Teach It?" (May 20), (accessed July 1, 2015), [available at http://www.economist. com/node/2685892].

(2014), "We Want to Be Your Friend," (February 1), (accessed July 1, 2015), [available at http://www.economist. com/news/business/21595412-brands-are-finding-it-hardadapt-age-scepticism-we-want-be-your-friend].

Ellis, Paul (2003), "Are International Trade Intermediaries Catalysts in Economic Development? A New Research Agenda," Journal of International Marketing, 11 (1), 73-96.

Escalas, Jennifer Edson and James R. Bettman (2005), "SelfConstrual, Reference Groups, and Brand Meaning," Journal of Consumer Research, 32 (3), 378-89.

Feather, N.T. and Rebecca Sherman (2002), "Envy, Resentment, Schadenfreude, and Sympathy: Reactions to Deserved and Undeserved Achievement and Subsequent Failure," Personality and Social Psychology Bulletin, 28 (7), 953-61.

Ferguson, Rick and Kelly Hlavinka (2007), "The COLLOQUY Loyalty Marketing Census: Sizing Up the US Loyalty Marketing Industry," Journal of Consumer Marketing, 24 (5), 313-21.

Ferraro, Rosellina, Amna Kirmani, and Ted Matherly (2013), "Look at Me! Look at Me! Conspicuous Brand Usage, Self-
Brand Connection, and Dilution," Journal of Marketing Research, 50 (4), 477-88.

Frynas, J drzej George, Kamel Mellahi, and Geoffrey Allen Pigman (2006), "First Mover Advantages in International Business and Firm-Specific Political Resources," Strategic Management Journal, 27 (4), 321-45.

Gailliot, Matthew T., Brandon J. Schmeichel, and Roy F. Baumeister (2006), "Self-Regulatory Processes Defend Against the Threat of Death: Effects of Self-Control Depletion and Trait Self-Control on Thoughts and Fears of Dying," Journal of Personality and Social Psychology, 91 (1), 49-62.

Garbarino, Ellen and Mark S. Johnson (1999), “The Different Roles of Satisfaction, Trust, and Commitment in Customer Relationships," Journal of Marketing, 63 (April), 70-87.

Garcia, Oscar, Jorge Lacayo, and Anne Martinze (2012), “Understanding Mexico's Evolving Customers," McKinsey \& Company, (August), (accessed July 1, 2015), [available at http://www.mckinsey.com/insights/consumer_and_retail/unde rstanding_mexicos_evolving_consumers].

Gibbons, Frederick X. and Bram P. Buunk (1999), "Individual Differences in Social Comparison: Development of a Scale of Social Comparison Orientation," Journal of Personality and Social Psychology, 76 (1), 129-42.

Giebelhausen, Michael, Stacey G. Robinson, Nancy J. Sirianni, and Michael K. Brady (2014), "Touch Versus Tech: When Technology Functions as a Barrier or a Benefit to Service Encounters," Journal of Marketing, 78 (July), 113-24.

Grayson, Kent, Devon Johnson, and Der-Fa Robert Chen (2008), "Is Firm Trust Essential in a Trusted Environment? How Trust in the Business Context Influences Customers," Journal of Marketing Research, 45 (April), 241-56.

Guillén, Mauro F. and Sandra L. Suárez (2005), "Explaining the Global Digital Divide: Economic, Political and Sociological Drivers of Cross-National Internet Use," Social Forces, 84 (2), 681-708.

Guseva, Alya and Akos Rona-Tas (2001), "Uncertainty, Risk, and Trust: Russian and American Credit Card Markets Compared," American Sociological Review, 66 (5), 623-46.

Henderson, Conor M., Joshua T. Beck, and Robert W. Palmatier (2011), "Review of the Theoretical Underpinnings of Loyalty Programs," Journal of Consumer Psychology, 21 (3), 256-76.

Henrich, Joseph, Jean Ensminger, Richard McElreath, Abigail Barr, Clark Barrett, Alexander Bolyanatz, et al. (2010), "Markets, Religion, Community Size, and the Evolution of Fairness and Punishment," Science, 327 (5972), 1480-84.

Heshmati, Almas (2006), "Measurement of a Multidimensional Index of Globalization," Global Economy Journal, 6 (2), 128 . 
Hofstede, Geert (1998), Masculinity and Femininity: The Taboo Dimension of National Cultures. Thousand Oaks, CA: Sage Publications.

Gert Jan Hofstede, and Michael Minkov (2010), Cultures and Organizations: Software of the Mind: Intercultural Cooperation and Its Importance for Survival. New York: McGraw-Hill.

_ and Michael Minkov (2010), "Long- Versus Short-Term Orientation: New Perspectives," Asia Pacific Business Review, 16 (4), 493-504.

Hofstede, Gert Jan, Catholijn M. Jonker, and Tim Verwaart (2008), "Long-Term Orientation in Trade," in Complexity and Artificial Markets, Klaus Schredelseker and Florian Hauser, eds. New York: Springer, 107-119.

Howlett, Elizabeth, Jeremy Kees, and Elyria Kemp (2008), “The Role of Self-Regulation, Future Orientation, and Financial Knowledge in Long-Term Financial Decisions," Journal of Consumer Affairs, 42 (2), 223-42.

Jap, Sandy D. (2001), "The Strategic Role of the Salesforce in Developing Customer Satisfaction Across the Relationship Lifecycle," Journal of Personal Selling and Sales Management, $21(2), 95-108$

Johnson, Michael D., Andreas Herrmann, and Frank Huber (2006), "The Evolution of Loyalty Intentions," Journal of Marketing, 70 (April), 122-32.

Jones, Michael A., David L. Mothersbaugh, and Sharon E. Beatty (2000), "Switching Barriers and Repurchase Intentions in Services," Journal of Retailing, 76 (2), 259-74.

Kale, Sudhir H. and John W. Barnes (1992), "Understanding the Domain of Cross-National Buyer-Seller Interactions," Journal of International Business Studies, 23 (1), 101-132.

and Roger P. McIntyre (1991), "Distribution Channel Relationships in Diverse Cultures," International Marketing Review, 8 (3), 31-45.

Kaynak, Erdener and Paul Herbig (2014), Handbook of CrossCultural Marketing. London: Routledge.

Keillor, Bruce D. and G. Tomas M. Hult (1998), "A Five-Country Study of National Identity: Implications for International Marketing Research and Practice," International Marketing Review, 16 (1), 65-82.

- James Kohut, Donna M. Walsh, and Douglass Hausknecht (2011), "Global Product Strategy: A Longitudinal Multi-Country Product Attribute Study," Marketing Management Journal, 21 (1), 124-39.

Keller, Punam Anand and Lauren Goldberg Block (1996), "Increasing the Persuasiveness of Fear Appeals: The Effect of
Arousal and Elaboration," Journal of Consumer Research, 22 (4), 448-59.

Kim, Youngseon and Yinlong Zhang (2014) “The Impact of Power-Distance Belief on Consumer Preference for Status Brands," Journal of Global Marketing, 27 (1), 13-29.

Kitayama, Shinobu, Batja Mesquita, and Mayumi Karasawa (2006), "Cultural Affordances and Emotional Experience: Socially Engaging and Disengaging Emotions in Japan and the United States," Journal of Personality and Social Psychology, 91 (5), 890-903.

Kivetz, R.A.N. and Itamar Simonson (2003), "The Idiosyncratic Fit Heuristic: Effort Advantage as a Determinant of Consumer Response to Loyalty Programs," Journal of Marketing Research, 40 (November), 454-67.

Kramer, Roderick M., Debra Meyerson, and Gerald Davis (1990), "How Much Is Enough? Psychological Components of 'Guns Versus Butter' Decisions in a Security Dilemma," Journal of Personality and Social Psychology, 58 (6), 984-93.

Kumar, V., Eli Jones, Rajkumar Venkatesan, and Robert P. Leone (2011), "Is Market Orientation a Source of Sustainable Competitive Advantage or Simply the Cost of Competing?" Journal of Marketing, 75 (January), 16-30.

Amalesh Sharma, Riddhi Shah, and Bharath Rajan (2013), "Establishing Profitable Customer Loyalty for Multinational Companies in the Emerging Economies: A Conceptual Framework," Journal of International Marketing, 21 (1), 57-80.

Kuznets, Simon (1955), "Economic Growth and Income Inequality," American Economic Review, 45 (1), 1-28.

Lam, Desmond, Alvin Lee, and Richard Mizerski (2009), “The Effects of Cultural Values in Word-of-Mouth Communication," Journal of International Marketing, 17 (3), 55-70.

Laroche, Michel, Maria Kalamas, and Mark Cleveland (2005), “'I' Versus 'We," International Marketing Review, 22 (3), 279-308

Liu, Ya, Zhenhong Wang, and Wei Lu (2013), "Resilience and Affect Balance as Mediators Between Trait Emotional Intelligence and Life Satisfaction," Personality and Individual Differences, 54 (7), 850-55.

Liu-Thompkins, Yuping and Leona Tam (2013), "Not All Repeat Customers Are the Same: Designing Effective CrossSelling Promotion on the Basis of Attitudinal Loyalty and Habit," Journal of Marketing, 77 (September), 21-36.

Loughnan, Steve, Peter Kuppens, Jüri Allik, Katalin Balazs, Soledad de Lemus, Kitty Dumont, et al. (2011), "Economic Inequality Is Linked to Biased Self-Perception," Psychological Science, 22 (10), 1254-58. 
Luo, Anita and V. Kumar (2013), "Recovering Hidden BuyerSeller Relationship States to Measure the Return on Marketing Investment in Business-to-Business Markets," Journal of Marketing Research, 50 (February), 143-60.

Mandel, Naomi (2003), "Shifting Selves and Decision Making: The Effects of Self-Construal Priming on Consumer RiskTaking," Journal of Consumer Research, 30 (1), 30-40.

Marketing Science Institute (2014), “2014-2016 Research Priorities," (accessed July 1, 2015), [available at http://www.msi. org/research/2014-2016-research-priorities/].

McGraw, A. Peter and Philip E. Tetlock (2005), “Taboo TradeOffs, Relational Framing, and the Acceptability of Exchanges," Journal of Consumer Psychology, 15 (1), 2-15.

Mende, Martin, Ruth N. Bolton, and Mary Jo Bitner (2013), "Decoding Customer-Firm Relationships: How Attachment Styles Help Explain Customers' Preferences for Closeness, Repurchase Intentions, and Changes in Relationship Breadth," Journal of Marketing Research, 50 (February), $125-42$.

Moeller, Miriam and Michael Harvey (2011), "Inpatriate Marketing Managers: Issues Associated with Staffing Global Marketing Positions," Journal of International Marketing, 19 (4), $1-16$.

Moorman, Christine, Gerald Zaltman, and Rohit Deshpandé (1992), "Relationships Between Providers and Users of Market Research: The Dynamics of Trust Within and Between Organizations," Journal of Marketing Research, 29 (August), 314-29.

Morales, Andrea C. (2005), "Giving Firms an 'E' for Effort: Consumer Responses to High-Effort Firms," Journal of Consumer Research, 31 (4), 806.

Morgan, Robert M. and Shelby D. Hunt (1994), “The Commitment-Trust Theory of Relationship Marketing," Journal of Marketing, 58 (July), 20-38.

Muraven, Mark and Roy F. Baumeister (2000), "Self-Regulation and Depletion of Limited Resources: Does Self-Control Resemble a Muscle?" Psychological Bulletin, 126 (2), 24759.

Murray, Kyle B. and Gerald Häubl (2007), "Explaining Cognitive Lock-In: The Role of Skill-Based Habits of Use in Consumer Choice," Journal of Consumer Research, 34 (1), 7788 .

Nelson, Colin (2011), "The Global Spread of Business School Accreditation,” blog entry, AACSB International, (August 31), (accessed July 1, 2015), [available at http://aacsbblogs.typepad.com/dataandresearch/2011/08/the-global-spread-ofbusiness-school-accreditation.html].
Noordhoff, Corine, Pieter Pauwels, and Gaby OdekerkenSchröder (2004), "The Effect of Customer Card Programs: A Comparative Study in Singapore and the Netherlands," International Journal of Service Industry Management, 15 (4), 351-64.

O'Brien, Daniel Tumminelli and David Sloan Wilson (2011), "Community Perception: The Ability to Assess the Safety of Unfamiliar Neighborhoods and Respond Adaptively," Journal of Personality and Social Psychology, 100 (4), 606-620.

Oishi, Shigehiro, Selin Kesebir, and Ed Diener (2011), "Income Inequality and Happiness," Psychological Science, 22 (9), 1095-1100.

Ordabayeva, Nailya and Pierre Chandon (2011), “Getting Ahead of the Joneses: When Equality Increases Conspicuous Consumption Among Bottom-Tier Consumers," Journal of Consumer Research, 38 (1), 27-41.

Palmatier, Robert W., Rajiv P. Dant, Dhruv Grewal, and Kenneth R. Evans (2006), "Factors Influencing the Effectiveness of Relationship Marketing: A Meta-Analysis," Journal of Marketing, 70 (July), 136-53.

, Mark B. Houston, Rajiv P. Dant, and Dhruv Grewal (2013), "Relationship Velocity: Toward a Theory of Relationship Dynamics," Journal of Marketing, 77 (January), 13-30.

, Cheryl Burke Jarvis, Jennifer R. Bechkoff, and Frank R. Kardes (2009), "The Role of Customer Gratitude in Relationship Marketing," Journal of Marketing, 73 (September), 1-18.

Pariser, Eli (2011), The Filter Bubble: What the Internet Is Hiding from You. London: Penguin.

Patterson, Paul G. and Tasman Smith (2003), "A Cross-Cultural Study of Switching Barriers and Propensity to Stay with Service Providers," Journal of Retailing, 79 (2), 107-120.

Payne, Adrian and Pennie Frow (2005), “A Strategic Framework for Customer Relationship Management," Journal of Marketing, 69 (October), 167-76.

Perugini, Marco, Marcello Galluci, Fabio Presaghi, and Anna Paola Ercolani (2003), "The Personal Norm of Reciprocity," European Journal of Personality, 17 (4), 251-83.

Piketty, Thomas (2014), Capital in the Twenty-First Century. Cambridge, MA: Harvard University Press.

Pornpitakpan, Chanthika and June N.P. Francis (2000), "The Effect of Cultural Differences, Source Expertise, and Argument Strength on Persuasion: An Experiment with Canadians and Thais," Journal of International Consumer Marketing, 13 (1), 77-101.

Robertson, Thomas S. and Hubert Gatignon (1986), "Competitive Effects on Technology Diffusion," Journal of Marketing, 50 (July), 1-12. 
Ross, Catherine E., John Mirowsky, and Shana Pribesh (2001), "Powerlessness and the Amplification of Threat: Neighborhood Disadvantage, Disorder, and Mistrust," American Sociological Review, 66 (4), 568-91.

Samaha, Stephen A., Joshua T. Beck, and Robert W. Palmatier (2014), "The Role of Culture in International Relationship Marketing," Journal of Marketing, 78 (September), 78-98.

Schneider, Joan and Julie Hall (2011), "Why Most Product Launches Fail," Harvard Business Review, (April), (accessed July 1, 2015), [available at https://hbr.org/2011/04/why-mostproduct-launches-fail].

Schumpeter, Joseph Alois (1934), The Theory of Economic Development: An Inquiry into Profits, Capital, Credit, Interest, and the Business Cycle. Piscataway, NJ: Transaction Publishers.

Shah, Denish, V. Kumar, and Kihyun Hannah Kim (2014), "Managing Customer Profits: The Power of Habits," Journal of Marketing Research, 51 (December), 726-42.

Silverblatt, Howard and Dave Guarino (2011), "S\&P 500: 2010 Global Sales,” in S\& P Indices. New York: Standard \& Poor's.

Skarmeas, Dionisis, Constantine S. Katsikeas, and Bodo B. Schlegelmilch (2002), "Drivers of Commitment and Its Impact on Performance in Cross-Cultural Buyer-Seller Relationships: The Importer's Perspective," Journal of International Business Studies, 33 (4), 757-83.

Sojka, Jane and Patriya S. Tansuhaj (1995), "Cross-Cultural Consumer Research: A Twenty-Year Review," in Advances in Consumer Research, Vol. 22, Frank R. Kardes and Mita Sujan, eds. Provo, UT: Association for Consumer Research, 461-74.

Stahl, Florian, Mark Heitmann, Donald R. Lehmann, and Scott A. Neslin (2012), “The Impact of Brand Equity on Customer Acquisition, Retention, and Profit Margin," Journal of Marketing, 76 (July), 44-63.

Steenkamp, Jan-Benedict E.M. (2001), “The Role of National Culture in International Marketing Research," International Marketing Review, 18 (1), 30-44.

and Martijn G. de Jong (2010), “A Global Investigation into the Constellation of Consumer Attitudes Toward Global and Local Products," Journal of Marketing, 74 (November), $18-40$

Steensma, H. Kevin, Louis Marino, K. Mark Weaver, and Pat H. Dickson (2000), "The Influence of National Culture on the Formation of Technology Alliances by Entrepreneurial Firms," Academy of Management Journal, 43 (5), 951-73.

Steinhoff, Lena and Robert W. Palmatier (2014), "Understanding Loyalty Program Effectiveness: Managing Target and
Bystander Effects," Journal of the Academy of Marketing Science, 5 (August), 1-20.

Sternthal, Brian and C. Samuel Craig (1974), "Fear Appeals: Revisited and Revised," Journal of Consumer Research, 1 (3), 22-34.

Swodoba, Bernhard and Stefan Elsner (2013), "Transferring the Retail Format Successfully into Foreign Countries," Journal of International Marketing, 21 (1), 80-109.

Tellis, Gerard J., Stefan Stremersch, and Eden Yin (2003), “The International Take-Off of New Products: The Role of Economics, Culture, and Country Innovativeness," Marketing Science, 22 (2), 188-208.

Thomas, Nicholas and William T. Tow (2002), "The Utility of Human Security: Sovereignty and Humanitarian Intervention,” Security Dialogue, 33 (2), 177-92.

Tobias, Robert (2009), “Changing Behavior by Memory Aids: A Social Psychological Model of Prospective Memory and Habit Development Tested with Dynamic Field Data," Psychological Review, 116 (2), 408-438.

Tuli, Kapil R., Sundar G. Bharadwaj, and Ajay K. Kohli (2010), "Ties That Bind: The Impact of Multiple Types of Ties with a Customer on Sales Growth and Sales Volatility," Journal of Marketing Research, 47 (February), 36-50.

Van de Ven, Niels, Marcel Zeelenberg, and Rik Pieters (2009), "Leveling Up and Down: The Experiences of Benign and Malicious Envy," Emotion, 9 (3), 419-29.

— - - (2011), "The Envy Premium in Product Evaluation," Journal of Consumer Research, 37 (6), 984-98.

Voss, Chris, Aleda V. Roth, and Richard B. Chase (2008), "Experience, Service Operations Strategy, and Services as Destinations: Foundations and Exploratory Investigation," Production and Operations Management, 17 (3), 247-66.

Wang, C.L. (2007), “Guanxi vs. Relationship Marketing: Exploring Underlying Differences," Industrial Marketing Management, 36 (1), 81-86.

Watson, John J., Ruth S. Rayner, Steven Lysonski, and Srinivas Durvasula (1999), Vanity and Advertising: A Study of the Impact of Appearance-Related, Sex, and Achievement Appeals. Provo, UT: Association for Consumer Research.

Weber, Elke U. and Christopher Hsee (1998), "Cross-Cultural Differences in Risk Perception, but Cross-Cultural Similarities in Attitudes Towards Perceived Risk," Management Science, 44 (9), 1205-1217.

White, K. and Darren W. Dahl (2006), "To Be or Not Be? The Influence of Dissociative Reference Groups on Consumer 
Preferences," Journal of Consumer Psychology, 16 (4), 404414.

Williams, Jerome D., Sang-Lin Han, and William J. Qualls (1998), "A Conceptual Model and Study of Cross-Cultural Business Relationships," Journal of Business Research, 42 (2), 135-43.

Wood, Wendy and David T. Neal (2009), “The Habitual Consumer," Journal of Consumer Psychology, 19 (4), 579-92.

Woolcock, Michael (1998), "Social Capital and Economic Development: Toward a Theoretical Synthesis and Policy Framework," Theory and Society, 27 (2), 151-208.
World Bank (2014), World Development Indicators. Washington, DC: World Bank.

Zeriti, Athina, Matthew J. Robson, Stavroula Spyropoulou, and Constantinos N. Leonidou (2014), "Sustainable Export Marketing Strategy Fit and Performance," Journal of International Marketing, 22 (4), 44-66.

Zhou, Lianxi and Michael K. Hui (2003), "Symbolic Value of Foreign Products in the People's Republic of China," Journal of International Marketing, 11 (2), 36-58. 
Copyright of Journal of International Marketing is the property of American Marketing Association and its content may not be copied or emailed to multiple sites or posted to a listserv without the copyright holder's express written permission. However, users may print, download, or email articles for individual use. 